\title{
hope for/against the state: gridding in a besieged Sarajevo suburb
}

\author{
stef jansen \\ university of manchester
}

\begin{abstract}
Anthropological dealings with the state often convey hope by replicating the hope of their subjects against the state. This libertarian paradigm provides effective analytical tools to grasp people's evasion of state grids, through cultural resilience-in-authenticity and/or autonomous self-organisation. Yet it cannot conceptualise their affective and practical investments in ordering statecraft, i.e. their hope for the state. Through a case study of self-organisation in the besieged outskirts of Sarajevo, Bosnia and Herzegovina, this article traces inhabitants' yearnings for 'normal lives' and their efforts to allow the latter to unfold. I focus on schooling and its temporal calibration of routines, framed in the vertical encompassment of statecraft. Against the reduction of hope to hope against the state, the complementary analytical tool of 'gridding', I propose, allows an alternative form of replication, capturing people's yearnings for the convergence of topdown and upward/outward organisation of predictability on different scales.
\end{abstract}

[key words: state, hope, normal lives, gridding, Bosnia and Herzegovina]

\section{anthropology of/against the state}

Much anthropology of the state is anthropology against the state in at least two ways: empirically, it privileges its subjects' evasion of statecraft, and politically, it locates its own hope in those subjects' hope for evasion. A particularly eloquent example is James Scott's sustained critique of rational state-organised attempts to tame the unruly diversity of people, places and things in 'a standard grid whereby it could be centrally recorded and monitored', and thus governed (1998: 2). For Scott, state grids always appear as imposed on people, seeking to replace bottom-up, authentic, local self-development with a top-down, inauthentic, larger-thanlocal system aimed at discipline and expropriation. He argues that such grid impositions necessarily fail due to their disrespect for mettis, people's local, experiential wisdom, embodied in collective terms by '(civil) society', posited as separate from and opposed to the state. Scott's The Art Of Not Being Governed (2009) celebrates how Southeast Asian hill people purposefully evaded state grids, maintaining political autonomy and, at most, entering a mutual parasitical relationship with them.

If Scott's book is a self-confessed epitaph for a disappeared world-with its polemical verve offset by a knowing resignation that is written after hope-David Graeber does not see state enclosure as ever-increasing. Tracing grid evaders in rural Madagascar, he emphasises self-organisation instead, seeing the establishment of 'provisional zones of autonomy' as hopeful signs 'that alternatives are still conceivable, that human possibilities are never fixed' (2007: 172). In Madagascar, Graeber argues, autonomy emerged from a convergence of people's desire to self-organise, based on their awareness of the arbitrary, coercive nature of the state, and of the government's disinterest and incapacity to impose grids on them. People's limited, tactical engagements with state grids ultimately served as reminders of their opposite: 'the Malagasy way' of ungridded self-government through consensual egalitarianism. The state, Graeber argues, existed only as a hollow 'scam' (2007: 169).

In divergent ways, Scott and Graeber seek to 'replicate' (Miyazaki 2004) the hope of their subjects for autonomy from the state, thus formulating hope for an anthropology that enriches political imaginations impoverished by state-centred thinking. Both authors position their 
analyses as subversive of dominant knowledge production. They do indeed provide politically valuable antidotes against the suppression of grid evasion in official state narratives, but, at least since Clastres (1974), such suppression is hardly dominant in anthropological treatments of statecraft. When it comes to the study of self-proclaimed modern ordering schemes, such as states, anarchist writings represent particularly consistent and well-developed crystallisations of a paradigm - a format of questions asked and of ways to seek answers-that has permeated much anthropology for decades (Spencer 2007; Critique of Anthropology 2012). This libertarian paradigm $^{1}$ posits the state predominantly as an imposed externality, approached along two separate analytical paths. The first path, often inspired by Gramsci or Foucault, unmasks topdown modern statecraft's claims to enlightened progress. The second one documents people's resilience in opposition to, or oblivious to, statecraft thus conceived.

Far from being the preserve of anarchist anthropology, the libertarian paradigm combines favourite ingredients of our discipline more broadly: e.g. a celebration of difference, an emphasis on modernity's discontents, a privileging of small-scale phenomena, and sympathy for (often culturally conceived) underdogs who generally favour 'authentic' resilience over 'modern' change. We find varying degrees of activist intent, and differential emphases on culture, but with regard to the operation of modern grids a convergence exists around a conception of anthropology as being particularly apt for the study of local, authentic, diverse resilience. As anthropologists we thus become experts on how people resist, ignore, or, at most, cleverly accommodate to top-down ordering schemes.

The popularity of this libertarian paradigm is, I suggest, not merely an analytical reflection of our interlocutors' libertarianism. It is at least also (and perhaps mainly) a function of the hope it allows for anthropologists. Through replication of the hope of our subjects, it promises a lasting political purpose for anthropology. Tracing how, against all odds, plucky little people throw spanners in large-scale grids and retain difference against standardisation, we can reinvigorate our hope for humanity by uncovering political hope where we could have mistakenly feared there was none. Furthermore, this paradigm seems to rely on a broader assumption on human nature too: combining anthropology's romantic anti-modern roots with a Camusian affirmation of L'Homme revolté (1985), it suggests that, ultimately, people prove their humanity through authentic grid evasion. Especially if authenticity is conceived of as cultural, this allows identification with resistant underdogs by sympathetic anthropologists. ${ }^{2}$ In that way, the libertarian paradigm also facilitates the replication of people's hope against the state in the search for our discipline's continued relevance.

\section{'gridding' and 'normal lives'}

Studies in the libertarian paradigm, whether by self-identified anarchists or by others, have proven extremely valuable. With regard to statecraft, a key contribution lies in their insistent documentation of the contingency of state-making and the often catastrophic realities behind triumphalist, teleological state narratives. Against reason(ing)s of state, they provide effective analytical tools to critically deconstruct statecraft, to theorise people's evasion of it and thus to facilitate the imagining of alternatives.

As we saw, studies of the state and of grid evasion are usually conducted as analytically separate routes of investigation rather than by treating them as a single matter of concern. A critical unmasking of oppression, disciplining and manipulation through state grids occurs alongside a celebratory analysis of people's resistance to them. This reinforces the assumed boundary between 'state' and 'society', or, allowing for the political charge of most such work, between the insiduousness of modern statecraft and the beauty of resilience-in-authenticity. This article seeks to learn from recent writings that aim to overcome this dichotomous model (e.g. Das \& Poole 2004; Hansen \& Stepputat 2001) but also attempts to extend them in a particular direction. This is because on two specific accounts such writings often leave me 
dissatisfied. Firstly, despite statements of intent, empirically, many such studies still (separately) focus on top-down disciplining schemes and people's evasion attempts, paying little attention to their non-evasion. Secondly, when hopes for the state are acknowledged, they are incorporated all too easily into the author's hope against the state: since the analyst unmasks the state as an ideological construct, people's investments in it are swiftly reduced to internalisations of the insidious circularity of statecraft. State grids are thus still mainly conceived of as imposed externalities and anthropologists still mostly focus on showing how people do-or at least could and should-evade them. To a large degree, the libertarian paradigm remains untouched.

In many anthropological studies there are sound political reasons to hold on to this paradigm and I salute such efforts. Yet here I want to argue that the paradigm's popularity and its great contributions come at a price. Its limits become especially visible in cases where libertarian hopes are not prominent amongst our research subjects, as in my 2008 and 2010 research in Dobrinja, a peripheral apartment complex in Sarajevo, the capital of BosniaHerzegovina (BiH). Over and above any grid evasion, I was struck by strong yearnings for 'normal lives' and, as part of that, for incorporation into a 'functioning state'. Clearly, that such hope for the state exists should not surprise anyone. My objective is not simply to draw attention to the fact that some people's hopes (and fears) do not sit easily with libertarianism. I want to probe the limits of the libertarian paradigm in analytical terms and try to develop complementary conceptual tools. Having become experts in grid evasion, I ask, how can we enrich anthropological understandings of grid desire? If we have an elaborate and effective toolbox for studying hope against the state, can we also develop concepts to grasp hope for the state? Short of dismissing it as false consciousness, successful disciplining, or feigned compliance, here anthropology offers a much poorer array of conceptual tools. In asking how we can anthropologically replicate hope for the state, this article thus seeks to contribute to an emerging body of anthropological work that theorises people's investment in statecraft in a non-dichotomous, integrated way, reluctant to locate people and their hopes always already outside of state grids (e.g. Corbridge et al. 2005; Dunn 2008; Li 2007; Navaro-Yashin 2002; Nuijten 2003; Obeid 2010; Reeves 2011; Spencer 2007; Ssorin-Chaikov 2003). ${ }^{3}$ Through a retrospective analysis of hope for the state in war-time Dobrinja, I propose we extend such existing work by adding 'gridding' to our conceptual toolbox.

In Dobrinja, I found that a sense prevailed that one lived after gridding, and that gridding was necessary to allow 'normal lives' to unfold. The emic category of normalan život ['normal life'] functioned as a consensual and normative label in a backward- and a forward-looking sense: 'normal life' was what one had lived in socialist Yugoslavia, and it was an aspiration for the future. This does not mean that people desired to have exactly the same life again. In both its past- and future-oriented modalities, 'normal life' remained vague-indeed, this made a degree of consensus possible. Importantly, 'normal life' emerged predominantly when discussing its absence in the 'abnormal' conditions that people felt had started with the war and that had so far failed to disappear. In contrast to studies in formerly Soviet-dominated Eastern Europe (e.g. Fehérváry 2002; Galbraith 2003; Rausing 2002), most research on 'normality' in the postYugoslav states does not focus on consumption. Moreover, ethnographically, previous lives do not feature as 'abnormal' experiences to be corrected by a return to the West, but overwhelmingly as a positive source for evocations of 'normality' (e.g. Greenberg 2011; Jansen 2005, 2008, 2009, 2010; Maček 2009; Stefansson 2006). As Jessica Greenberg argues on the basis of research in Serbia, 'normality' can function as a 'diagnostic category' (2011: 89). She explains, for example, how people's reluctance to invest in long-term relationships was linked to a lack of predictability and future perspectives, phrased as a lack of 'normality'. Notions of normality thus included a

'kind of predictability that would allow [one] to follow-through on commitments made to oneself and others, [to establish routines that] entailed an ability to render one's desires or personal commitments into an actionable truth' (Greenberg 2011: 93) 
In my work I opt to speak of 'normal life'. People in Dobrinja approached 'normality' in terms of lives: the ways in which they remembered they had lived, in which they lived now, and in which they hoped or feared to live tomorrow. This tension between familiarity and normativity and the simultaneous backward- and forward-orientation of yearnings for 'normal life' make them, I believe, a promising object of analysis. ${ }^{4}$

How then can we approach people's incorporations of statecraft into evocations of 'normal lives'? I suggest we reformulate Scott's conceptualisation of state-making around a singular 'standard grid' into a more multilayered, dynamic and plural understanding. A better, more three-dimensional term would be 'grid-matrix'. Stemming from the Latin root for 'mother', matrix also means 'womb' and refers to a substance within which something is enclosed, takes shape and develops. In anatomy, for example, it refers to the formative tissue from which a tooth or a nail develops, and in geology to the matter in which a fossil or crystal is embedded. Amongst its other meanings is that of a binding substance, like cement in concrete. To crystallise my dialogue with the libertarian paradigm, I stick with the term 'grid', understood as gridmatrix. This also allows me to emphasise crucial practical dynamics through the notion of 'gridding' (rather than the unacceptably clunky neologism 'grid-matrixing'). Grids, then, are adhoc cumulative results of ongoing gridding. They may grow, integrate and intensify, or shrink, disintegrate and lower intensity. If the grid metaphor conjures up mapmakers or administrators, who wish to make people and things legible - I turn it around to evoke people's routine reliance on cookers and light switches-and the pipe and wire grids in which this occurs.

Focussing on gridding as process and practice avoids the structural-functionalist emphasis on stasis and equilibrium and resonates with work on assemblages (Ong \& Collier 2005) and actor-networks (Latour 2005). Yet my entry point consists of yearnings for 'normal lives' and it is people who harbour them, not things, which requires a distinction between different kinds of 'actants' incompatible with actor-network theory. My analysis underscores Greenberg's point that desires for 'normality' evoke 'an external environment in which one has the agentive capacity to translate a promise or a wish into reality' (2011: 93). Yet, as we shall see, in besieged Dobrinja griddings were mobilised in an unstable, partial convergence of selforganisation and imposition that, to an extent, questions such 'externality'. 'Gridding', I propose, captures the intimate ways in which efforts to restore routines of 'normal life' were implicated in the production and functioning of ordering frameworks.

If state-making consists of contested gridding processes, the libertarian paradigm usefully confronts its facilitation of elite designs to discipline and expropriate. Yet gridding is not necessarily a state scheme and may consist of a variety of practices in different fields, on different scales and with different intensities. Importantly, gridding processes may unfold in interaction with each other and can be hierarchically nested: smaller-scale gridding may be dependent on and/or precipitate larger-scale gridding. Particularly, the degree to which statemaking is effective may be traced through the extent to which people experience institutionalised practices as gridded in 'vertical encompassment' (Ferguson and Gupta 2002). Let us now explore this in relation to besieged Dobrinja.

\section{the making of 'staircase schools'}

During the early days of the 1990s violence, many schools in BiH announced a premature end to the school year. For teachers, pupils and many parents, war thus started in part as an interruption of routines organised around the daily rhythms and longer-term trajectories of school work. The three primary schools of Dobrinja were not only closed in May 1992, but they were also destroyed by besieging Serbian nationalist forces.

By 1991, the late socialist apartment complex of Dobrinja housed over 30,000 inhabitants. It had a reputation as a middle-income dormitory suburb attracting young households from the 
city centre with relatively high levels of education. The 1991 census found no absolute majority of any nationality. However, by the time of the destruction of the schools and the closure of the siege, the majority of Serbs had left in a convergence of evacuations by the Serbian nationalist Srpska Demokratska Stranka (SDS, Serbian Democratic Party), intimidation by militias associated with SDS and with the Bosniak nationalist Stranka Demokratske Akcije (SDA, Party of Democratic Action), and their own belief that they would be better off 'with their own'. Especially after the proclamation and international recognition of the independent Republic of Bosnia and Herzegovina (RBiH) in April 1992 (as per referendum outcome), many Serbs moved to territories controlled by the besieging forces, the now Serbian-dominated Yugoslav People's Army, local militias and paramilitaries from Serbia. Others sought safety abroad. Many other Dobrinjci also left: especially women and children joined evacuation convoys, often intending to return soon, the latest by the start of the new school year. Meanwhile, the suburb started receiving displaced Bosniaks expelled from Eastern BiH by Serbian forces.

The latter quickly took some outlying parts of Dobrinja, imprisoning hundreds of civilians, but then their progress was blocked by hastily organised and logistically much inferior local units, including improvised 'guards' of individual apartment blocks and SDA militiassometimes operating in uneasy alliance. They were joined by $\mathrm{RBiH}$ government military and special police and later these formations merged into the Army of $\mathrm{BiH}(\mathrm{ARBiH})$. After the discovery of arms and of the signalling of targets to besiegers, remaining Serbs in Dobrinja came under increasing scrutiny as suspected fifth-columnists. Some were imprisoned or mistreatedoften by criminals-turned-commanders who operated semi-autonomously from local ARBiH structures, but with support from SDA figures in the RBiH government. These posed a threat to other Dobrinjci too. Many remaining Serbs fled through the lines. ${ }^{5}$ Prisoner exchanges followed and a temporary corridor allowed many women and children to move to the city centre. Some returned to Dobrinja some months later, when a precarious connection to the centre was established.

In the 1992-1995 war, Dobrinja was a relatively separate, heavily damaged suburb on the siege line with a drastically changed population due to inward, outward and internal movement (e.g. proportionally more adults, more men, more Bosniaks). Military defence was accompanied by the work of Civilna zaštita (CZ, Civil Protection), subordinated to the former. ${ }^{6} \mathrm{CZ}$ activities started with a population census and then included, for example: allocating accommodation to displaced persons; constructing anti-sniper shields, trenches and tunnels; repairing utilities (gas, electricity, sewage...), buildings (roofs, stairs...) and equipment (stoves, generators, bicycles...); sewing and washing soldier uniforms; digging water wells; running a fire brigade; maintaining hygiene (rubbish collection, pest control, water disinfection...); distributing humanitarian aid; coordinating burials between buildings; running public kitchens, hairdressers, a print shop and a music studio; creating a hospital; organising blood donations and breast screenings; staging cultural events; distributing seeds and advice on growing plants on balconies; and so on.

In addition to infrastructurally supporting the armed defence of Dobrinja, then, CZ coordinated efforts to mobilise the skills, knowledge and labour of Dobrinjci to guarantee survival and to re-establish functionality. It was in the extreme conditions of the early war period that the seeds for an emergency schooling system were planted. ${ }^{7}$

'On 15 May 1992 our school was shelled [...] They had already taken Dobrinja IV and [my family] had to move to Dobrinja II [a more central part]. On our own initiative, some of us started to gather children from the building in the staircase. I kept them busy with some lesson or activity. We wanted to protect the children, to keep them inside, but also to give them something to do, something valuable. To show them what was important, even then.'

This quotation is from an interview Mrs A, a Dobrinja teacher, who, after the destruction of her workplace, organised educational activities in staircases, the safest parts of the apartment blocks-hence the name that became common later: haustorske škole ['staircase schools']. 
Colleagues cut off from their schools elsewhere in the city joined in. Recalling those days, teachers often stressed their desire to establish a degree of meaningful routine. In the words of Mrs B, later the director of the Gimnazija (secondary school) in Dobrinja:

'During the war, different people reacted differently. Some fled, some withdrew into the basements, and some came out. We started all kinds of things then: schooling in the staircases, plans for this Gimnazija, all kinds of cultural manifestations... If you'd have asked me before the war, I'd never have been involved in anything like folklore, but during the war... we did. It seemed smarter to be busy with that than to think about which shell was going to kill you.'

Still in May 1992, the CZ Secretary for Schooling gained approval from municipal authorities, then cut off from Dobrinja, to form a 'Schooling Centre'. The military commander of Dobrinja allocated them a venue in a former games parlour. All teachers then present in Dobrinja were called to participate. Spontaneous initiatives were thus coordinated into a system. Classes were still organised in staircases and basements, referred to as punktovi, i.e. 'points', nodes in a network. To minimise pupils' exposure to shelling, teachers-mainly women-moved between punktovi through trenches. Mrs A continued her activities, now under the umbrella of the Schooling Centre, and others joined. Mobilisation for CZ work could include coercion, for example for trench-digging, but in their recollections many Dobrinja teachers emphasised their willing participation. Mothers of small children, for example, were exempted, but some volunteered anyway. Some men combined soldiering with teaching. Over the next three years, thousands of pupils participated in a system designed to provide education in extraordinary circumstances of siege.

'Catastrophic. [...] They constantly moved us between locations every few months. School was two-three times a week in the afternoon. I often completely forgot to go to school. Because after two-three years without any obligations, you totally lose the feeling what it means to have an obligation, to arrive somewhere on time, to go there, to be there, to do something. [...] Basements where we were, like, protected... and then they quickly rattle off five-six subjects. You, like, listen, manage to take some notes, and then another time is arranged. [...] Like the majority of kids, I finished with three notebooks and my level of knowledge in the end was zero.' (Pupil A, male, born 1979)

'Schooling in the staircases was chaotic, but somehow, incredibly, it worked... Improvised, everything changed all the time, there was heating or not, how much shelling... We re-used paper and wrote in tiny letters. We almost only had general subjects throughout the war-it was by the old curriculum, but they threw in some $\mathrm{BiH}$ writers. Class rooms were improvised, some teachers were real teachers from other schools, stuck here, some simply people who could and would teach something. I wrote my final history project about ancient Greece... I can't believe now that I could actually concentrate on that. But it was so boring that people focused on doing things that probably made no sense in those circumstances, but they devoted much attention and time to them. And so did I with my school work.' (Pupil B, female, born 1976)

Leaving aside their differing senses of achievement, those former pupils present a vivid picture of extremely abnormal conditions due to shelling and infrastructural problems. Mrs C, an elderly teacher, explained:

'Here in our building, in the basements, we organised primary and secondary schooling. We organised everything ourselves. Everyone who found themselves in Dobrinja and who was in the teaching profession, we all became active. So I went from punkt to punkt, and in one summer we completed an entire school year. Because we had no heating [...] We ran a truncated curriculum, adapted for war. This meant holes in the children's knowledge, but we had to. It was difficult for them to get used to, but there you go. They all took a little longer.' 


\section{'the class takes place': rhythms and trajectories of 'normal life'}

Education is often an instrument for state-led nationalist indoctrination, and there were such efforts by the SDA-dominated RBiH government too. Yet, like the recollections above, so the thousands of war-time entries of the School Diary of the Dobrinja Gimnazija, kept by its director, contain very little reference to Bosniakness, Islam, or nationality generally. Gimnazija personnel and pupils included people identifiable as non-Bosniaks, and indeed, the first pupil to be killed by shelling was one of them. The Diary does, unsurprisingly, display a close association with ARBiH, the army that defended Dobrinja against besieging forces and the ultimate authority in the suburb. Yet the main preoccupation in the Diary is one phrased as a determination to maintain civilisation while targeted by savagery. ${ }^{8}$ Evocations of the values of professionalism, knowledge and self-development prevail. A Gimnazija anniversary publication describes the first organised class, in January 1993, as follows:

'The class takes place and this is experienced as a miracle and also as a patriotic deed [...] Work and learning versus darkness and hatred, i.e. the civilisational duty of all those who decided to resist evil and destruction' (Šurković 2003: 5)

This class was a patriotic history lesson on $\mathrm{BiH}$ statehood, but what is considered patriotic about it here is the very act of running it. War-time sources and recollections recall a determination that life had to go on-insofar as possible, 'normal life'. Clearly, mentioning 'normal life' here derives its significance from the fact that life was anything but normal. It is against this background that the phrase 'the class takes place' gains its intended power as a descriptive statement. The message is: 'Despite everything, the class does take place'.

In her ethnography of besieged Sarajevo, Ivana Maček explains that such 'negotiations of normality' were crucial to civilian war experiences, involving an 'imitation of life' with ups and downs (2009: 62). Recalling this, some Dobrinjci spoke of 'surreality', detailing situations that would be unthinkable in 'normal life'-funny ones, scary ones, often both at the same time. Yet, especially in interviews, they too emphasised the defence of civilised humanity under uncivilised, inhuman siege. During the war, this representation was integrated in foreignoriented appeals by public figures in Sarajevo. Yet, beyond that, I heard many autobiographical war anecdotes about, for example, cooking dishes without required ingredients, cleaning without running water, and fashion within the bounds of clothing donations. In the 'abnormality' of almost four years of war, people thus recalled, they had tried, as much as possible, to maintain 'normality'. When seen within broader internal and external Balkanist representations of their predicament, it is easy to understand how that effort itself came to be considered a civilisational cause.

The School Diary too emphasises this 'up' dimension of Maček's cycle. Some entries report special events, such as an exhibition on the $10^{\text {th }}$ anniversary of the Sarajevo Winter Olympics, but most concern what would, in 'normal' circumstances, be non-spectacular routine. The dense 1993-1994 entries detail classes (dates and times, places, interruptions, number of pupils), the weather, the (un)availability of gas, electricity and water, food prices, humanitarian aid, struggles for space, equipment and heating (energy and safety problems remained when some central heating was installed in the Gimnazija in February 1994). Mentioning the relative intensity of shelling, many entries end with exhortations like 'We'll hold out! Despite everything, we are going on!' Sometimes they refer to material conditions only:

'Quiet in Dobrinja. There's gas, there's electricity. Briefly water too. Are we approaching civilisation?' (31/03/94)

On other days, there is a more general evocation of determination:

'All of Bosnia is waiting. Today the Geneva Convention starts its work on BiH. Regular classes are held, although working conditions are impossible. There's no water, no 
electricity, no gas, and still one lives well and works a lot. That is out of defiance [iz inata]. Such are the people from these parts: defiant and proud. Such will they remain and nothing can change them, not even this war.' (29/11/93)

Recollections of and war-time sources on Dobrinja schooling under siege thus often hinge on the gap between material circumstances and the conditions required for the rhythms and trajectories of 'normal' school activity. They highlight the civilisational value of education and infrastructural and safety problems of the staircase schools and signal an experience of temporal unmooring - a lack of regularity and predictability-as a key dimension of the 'abnormality' of siege circumstances (cf. Maček 2009: 64-70). They refer to the incessant revisions of timetables and locations, themselves due to the unpredictability of shelling and energy supply. This was, implicitly or explicitly, measured against the regimentation of schooling in 'normal life':

'I started the fifth year [of primary school] before the war, so I did not manage to finish it, and during the war I did the rest of my fifth, then my sixth, seventh and eighth year. And then on to secondary [education]. A school day... well, we had some timetable as in normal schools, shifts, but they were corrected according to the safety situation. [...] So our school day started with [...] running under sniper fire, shelling, to our basement. In the basement we tried to have some kind of normal schooling activity, until some shelling, some danger erupted, and then we had to interrupt class.' (Pupil C, male, born 1981).

This continuously frustrated effort to establish temporal structures more akin to 'normal life' had short- and long-term dimensions. On the short term, Dobrinja war-time schooling aimed to reinstitute school 'rhythms': the way in which school work calibrates routines through the standardised schedule of school days, of school weeks and weekends, and of school holidays. Here feasibility was determined mainly by the intensity of shelling and the availability of energy. Yet there were longer-term factors as well. In September 1994, for example, some pupils rejoined their original secondary schools elsewhere in Sarajevo, only to return a month later when transport was halted again (Šurković 2003: 25). This alerts us to the importance of what I call 'trajectories', the longer-term framework in which school 'rhythms' exist, and their cumulative effect. The trajectory associated here with schooling in 'normal life' is constructed around progression: every school year builds on the former, eventually leading to a diploma and, ideally, employment. Perhaps, then, it was a concern over irreversibly lost time in such trajectories-making adults out of children-that rendered education so important in Dobrinja attempts to re-establish 'normal' temporality.

Dobrinja had never had a secondary school, so teachers designed a system to provide pupils whose school year had been broken off with home study and consultation with appropriate teachers resident in the suburb. Initially, future reintegration into educational trajectories was facilitated through 'modified linear-programmed teaching units' and pupil records were maintained for transferral to their 'home' schools.

'They made it possible for us to sit exams for subjects with exceptional status. So that we wouldn't have to, we wouldn't lose, we wouldn't wait, because it wasn't known what would happen with the school system at all.' (Pupil D, female, 1974)

In January 1993, the Schooling Centre founded a Gimnazija in a network of punktovi. Some 330 pupils from different schools started classes, rising to 800 in Autumn 1994. Contractual regulations for teachers were established, involving some disputes. There were no salaries during the first eight months, but teachers sometimes received payment in kind or food vouchers. Yet these vouchers were worth little and availability of goods was minimal, so I suggest that, for teachers too, the temporal dimension was crucial. On the short term, contractual arrangements helped shape daily practice around rhythms of school work, and, on the longer term, they could pre-empt problems related to non-continuous employment (which 
did indeed amass after the war). They also provided recognition of teaching as professional work-an important factor given the value attributed to education and work in 'normal life'.

Central to the staircase schooling system in besieged Dobrinja are thus attempts to calibrate the flow of life back to 'normal'. The Schooling Centre tried to establish a degree of predictability, from the daily rhythms of schooling to the movement of pupils along a trajectory towards further study or employment, and that of teachers towards pension entitlements. Yearnings for 'normal lives', and the efforts to make them feasible, thus evoked a social configuration in which expectations were structured through their institutional embedding. I now show how the concept of 'gridding' may allow us to capture this analytically.

\section{self-organised upward and outward gridding}

In 1992, the planned suburb of Dobrinja was unmoored from its city centre and its gridding infrastructure was devastated. Yet this was far from a Hobbesian gridless situation. The proclamation of an independent RBiH attempted to detach it from what was left of Yugoslav gridding, upgrading grids of a federal unit to state ones. The army that many Dobrinjci had until recently considered to be a coercive guarantee-positively and negatively-of their gridding, had turned its artillery on those who favoured a RBiH grid, effectively siding with those in favour of a grid of a Serbian Republic of $\mathrm{BiH}$. This restructuring thus affected people differentially as they were now made legible through pro-BiH / anti-BiH gridding, partially articulated with nationality. In war-time Dobrinja an array of new, initially relatively autonomous gridding processes were set in motion to cope with violence, fear and destitution. The most effective capacity to impose these lay with the armed formations of the ARBiH and the CZ structures.

Key figures in CZ Dobrinja prided themselves on gridding organised civilian life as orderly and effectively as possible under siege. Similar processes, including the organisation of schooling, occurred elsewhere in $\mathrm{BiH}$, but Dobrinja was most frequently mentioned as an example. Military commanders emphasised how the defence of Dobrinja by poorly armed units, and indeed the survival of its population, had only been possible due to tight civilian organisation (Dobrinja Ratne novine 1992a: 3, 1992b:, 14; Oslobođenje 1994: 8). Indeed, they sometimes approvingly called war-time Dobrinja a 'little state' (e.g. Bećirović 2003). Recalling a famous case of self-organisation in Paris, a journalist described it as a 'Komuna' (Dobrinja Ratne novine 1992c: 2). Of course claims to successful state-making by those who considered themselves its leaders require scepticism. Some testimonies I gathered evoke a less egalitarian picture, in which the siege and violent claims to sovereignty by self-appointed strongmen on whose armed defence survival depended, posed an unequally distributed threat of a reduction to 'bare life' (Agamben 1998). Top-down gridding by CZ and ARBiH-e.g. through curfews and limited mobility - was therefore crucial to survival in this apartment complex on the siege line. Yet, threatened by besieging violence and potentially at the mercy of would-be sovereigns, a commitment to gridding emerged also precisely through yearnings to live beyond 'bare life'.

Proudly, and often contrasting it with post-war predicaments, many Dobrinjci told me that war-time Dobrinja really had been 'better organised' and that they had organised it themselves. ${ }^{9}$ Many other Sarajevans too confirmed that war-time Dobrinja-particularly initially - had been marred relatively less by looting, racketeering and misuse of humanitarian aid than the rest of the city. This was considered a major achievement in such a recent apartment complex: rather than pulling together as a long-standing, 'organically' grown community in defence of their common home, many Dobrinjci recalled how they had initially needed to build solidarity with neighbours they hardly knew. In the words of $\mathrm{Mr} \mathrm{D}$, a technician in CZ repair workshops throughout the war:

'In the beginning, no-one knew anyone. Everything had to be organised... and we organised everything.' 
Survival required cooperation, which required coordination. Anti-sniper shields, a hospital, flat allocation, humanitarian aid distribution-they all involved gridding. So did work on a gas pipe network towards the end of the war, when the city's public services still did not have maintenance teams in Dobrinja (Dobrinja Danas 27/03/95). In fact, people often related 'good organisation' precisely to the suburb's relative physical isolation from Sarajevo-based $\mathrm{RBiH}$ authorities. Over time, however, Dobrinja's reputation faded due to increasing attempts by central SDA figures to impose their priorities, including a more Bosniak nationalist vision, in all ARBiH-held territory (Oslobođenje 29/04/01:6).

A libertarian interpretation can handle this narrative. Some dimensions of the war-time organisation of Dobrinja by the military (ARBiH) and civil authorities (CZ) could be seen as miniature versions of the schemes lambasted by Scott (1998). While hardly in a position to cherish 'high modernist' aspirations, they could be represented as starting to 'see like a state' in order to ultimately become part of one. A libertarian analysis can celebrate self-governing, small-scale gridding in Dobrinja, and mourn its decline due to its vertical encompassment into $\mathrm{RBiH}$ state grids. Yet this would miss the point that these two griddings were not simply counterposed to each other, although they sometimes were in some ways. To understand how this tension worked, let us analyse war-time schooling as a contingent, partial convergence of self-organised and imposed gridding. Both attempted to incite certain activities, models of behaviour and temporal rhythms and trajectories of practice. Convergences always remained unstable and contested: e.g. teachers felt classes should be held despite of CZ warnings; conflicts over space emerged between the Schooling Centre and CZ officials; some resented increasing SDA interference. Yet gridding per se was not contested much. Actually, schooling initiatives always included a gridding dimension beyond itself-reaching 'upward' and 'outward' into the vertical encompassment of $\mathrm{RBiH}$ state-making.

The Schooling Centre could only operate with approval from the suburb's military commanders, who incorporated it in their own embryonic state-making projects. But its efforts to grid its activities upward and outward went beyond that. Even when gathering children on their own initiative as the siege closed around them, some teachers kept school diaries, listing the space, age group, number of children present and class theme (Musić 1998: 11). This followed an administrative format, and the later School Diary too was maintained according to a surviving socialist law. The Schooling Centre, coordinating teaching activities, immediately sought approval from municipal and state institutions. Shortly after its opening in 1993, the Gimnazija received a 'Decision' from the RBiH Ministry for Education, Science and Sports confirming it fulfilled the conditions to function as a public schooling institution according to curricular requirements (Šurković 2003: 15).

While keen to safeguard their autonomy in some ways, schooling initiatives thus included attempts to have local gridding vertically encompassed into gridding understood to be higher and broader. In addition to curricula and administrative procedures, we saw how such upward and outward gridding concerned accreditation of marks and diplomas and contractual arrangements for personnel, aiming for continuity in the educational trajectories of pupils and in the employment trajectories of teachers. The 'linear-modular module' set up to provide continuity for secondary school pupils was then further developed in collaboration with the Department of Pedagogy at the University of Sarajevo and the Pedagogical Institute. From Spring 1994 the Gimnazija was included in the latter's inspection rota, and, with its approval, the 'Dobrinja model' was later applied elsewhere in RBiH (Šurković 2003).

This last point not only highlights the mutual constitution of self-organised and imposed gridding, but also alerts us to a more symbolic dimension of Dobrinja's upward and outward gridding. Aretxaga has argued that we should see the state 'as the subject of excess that bypasses any rational functionality. What articulates this excess is fantasy' (2003: 402). In Dobrinja we found a strong pride in self-organisation, but also in practices that explicitly sought to call the state into being. For many this included a patriotic commitment to RBiH state-making, yet even this 'fantasy' dimension consisted to an extent of desires to establish rhythms and 
trajectories. The state was then called forth as the hoped-for structural effect of multi-layered gridding processes in vertical encompassment. For example, teachers proudly recalled that the Gimnazija secretary walked the risky $10 \mathrm{~km}$ to the city centre, across the barricades, to get an official stamp for the school. 'Work is victorious! Good luck!', says the Diary entry (10/07/93). We should not reduce this to tactical pretence only-to a 'scam'. The hope invested in this stamp included hope for ratification of the Gimnazija as a 'real' school, by standards of 'normal life', for recognition of its teaching activities in their contents (curricula), methods (models of teaching), products (certificates and diplomas) and labour (teacher employment). And those hopes, in turn, were embedded in hope for one's own survival and, often seen in conjunction, $\mathrm{RBiH}$ statehood.

If we think of states as the effects of practices, schooling in war-time Dobrinja can be considered an example of nesting gridding projects that contribute to state-making. Teachers aimed to re-establish rhythms and trajectories of 'normal' school work; they sought to grid these gridding activities upward and outward into institutional statecraft; and the largest-scale grid of vertical encompassment considered here-that of the state of $\mathrm{RBiH}$-was itself attempting to reduce its precariousness through seeking upward and outward gridding in a grid of states. On every scale this involves a desire for upward and outward gridding into a more vertically encompassing grid. And the temporal dimension is central: it is practices that are gridded here, small or big future-oriented projects that require some predictability shaped by gridding-from getting drinking water in an apartment complex in order to survive, to completing one's studies in order to potentially enter an employment trajectory. This is what 'normal lives' in Dobrinja were deemed to require: a far cry from a wish for ungridded freedom, we find pride in bottom-up self-organisation that seeks gridding.

\section{limits of libertarian critique}

This article insists anthropologists should attempt to account both for hope for and hope against the state, overcoming the tendency to flatten out grid desire in a dichotomous model that registers gridding predominantly in terms of imposition and evasion. It analyses the experiences of people who remember 'normal lives' within state grids and who self-consciously position themselves as righteous participants in a world structured by them. 'Normal lives' in Dobrinja have long integrated cookers and light switches, as well as the less obviously material infrastructural-but no less gridding, and no less expected-work of schooling. I found that the normative self-evidence of such gridding was emphasised through exasperated confrontations with the fact that during war-time it was not self-evident at all. Most Dobrinjci recalled the outbreak of war as a shock of sudden ungridding. They were forced to collect water from outside wells, to grow vegetables on balconies, to bury their own dead between parking lots and to carry out household chores without electrical equipment. Some experiential knowledgemètis - of elderly household members, who had once led less gridded lives, helped people cope with siege conditions. This, of course, would be a ready-made topic for anthropological analysis, so attuned to small-scale resilience understood as cultural. A replication of the hope embodied in this resilience could spark both political hope for ungridded autonomy and hope for anthropology as the specialist study of it. Yet while Dobrinjci sometimes recalled this with amusement, I never heard it represented as an emancipatory return to authentic autonomy. More commonly it was deplored as humiliating.

As well as evoking humiliation, fear, worry, cold and poverty, many contrasted life under siege with post-war conditions through positive references to war-time solidarity and to what they as Dobrinjci-thrown back on themselves—had collectively been capable of. And this itself was frequently phrased in terms of gridding. Mrs E, a key CZ activist, said: 
'First we did a population census. I went from flat to flat, 700 of them, writing down every man, woman and child. Then we set up the schooling system and a folklore group and a women's choir. Za vrijeme rata, bili smo super [During the war, we were great].'

Not everyone was as committed to war-time gridding as Mrs E, who was also an SDA member at the time. People are not equally able to mobilise nodes in particular griddings. Indeed, they may not want to. Clearly, besieged Dobrinjci did not hope to become automatons in a perfectly predictable environment. Ideally incorporation into gridding would be on their terms, and yearned-for 'normal lives' were projected to be calibrated by a degree of predictability. Grid evasion existed in tension with grid desire. One could view Mrs E, and teachers for that matter, as state agents with much to gain from gridding, but it has to be understood that Mrs E's own children went to the staircase schools. Likewise, the workers who constructed sniper-shields, and their loved ones, themselves hoped to be protected by them. In the gridding of besieged Dobrinja-involving armed defence, census-taking, trench-digging, food distribution, schooling, etc.-the combined concern for physical survival and a 'beyond-bare life' starkly exposes the interdependence of claims to territorial sovereignty, disciplinary technologies and the improvement of the condition of the population (Foucault 1991).

Seeking to replicate hopes for authentic, autonomous, self-conscious grid evasion, libertarian analyses cannot account for practices of grid desire. In besieged Dobrinja, spontaneous and CZ coordinated activities set in motion replacement gridding bounded and made possible by military discipline. The 'population' that was thus produced-people who had remained in Dobrinja and displaced persons-engaged with this in different ways. All submitted to a degree, since some gridding was coerced and survival was dependent on it, but here too some tried to evade discipline and mobilisation. Anthropology's libertarian tradition provides conceptual tools to investigate such resistance. However, Dobrinjci directed my focus instead to hope for gridding. These appeared not only in school documents or other 'official' sources. People who spent the war years there did not predominantly recall the gridding of war-time Dobrinja, including its vertical encompassment into RBiH state grids, as imposed. Nor was engagement with it remembered mainly as a 'scam', whether in terms of schooling, other CZ work, or ARBiH defence. Self-organisation was crucial to recollections, but people recalled their determination to restore rhythms and trajectories of 'normal life' not simply as resilient acts of spontaneous improvisation, nor only as autonomous self-organisation, but also as selforganised upward and outward gridding for improvement, including vertical encompassment into RBiH state griddings.

Recollections of the staircase schools in Dobrinja called forth a state itself embodied in a set of performative grids that, ideally, would calibrate 'normal lives'. In the post-war period, when barricades and snipers had disappeared, School Diary entries increasingly depicted Dobrinja as a neglected periphery. Having won a battle for its continued existence, the Gimnazija finally moved to purpose-built accommodation in 2010. This could be deplored as imposed vertical encompassment into disciplining statecraft, a sad end to autonomous selforganisation. In contrast, teachers themselves now integrated their self-organised activism under siege as the first episode of a contested, stop-start campaign to grid their work upwardly and outwardly, on their terms, into a state education system, although the relevant institutions were no longer those of $\mathrm{RBiH}$, which expired with the 1995 Dayton Peace Agreement, but those of Kanton Sarajevo.

This last point is important. During my research in 2008-10, many Dobrinjci bemoaned insufficient state gridding as one key reason why they were still unable to lead 'normal lives'. Libertarian critiques of disciplinary and aspiring panoptical state power seem powerless here. Postsocialist, post-Yugoslav, and then post-war transformations in BiH drastically restructured state griddings-this included some forms of neoliberalisation, the constitutional cementing of nationalist division and dispersion of institutional gridding capacity. A radical case of the 'postpresence of the state' (Dunn 2008: 254), 'the state' was not experienced as aspiring or able to make everything and everyone legible, to govern rationally through standardised gridding, let alone to improve the population. Fifteen years after the war, rather than predominantly being 
feared for suppressing authentic freedoms, Dobrinjci first and foremost resented 'the state' for not being enough of a state where it counted. Sometimes evading it in some ways, they were also engaged in efforts to see it in the first place, and to be seen by it. Clamouring for legibility, they sought gridding to create conditions in which 'normal lives' could unfold. It is against this background that they proudly-and with some melancholy-recalled their own war-time efforts to self-organise in solidarity, and the upward and outward gridding efforts this had included. Here, anthropological championings of evasions of the state's gaze and grasp, the backbone of the political critique embodied by the libertarian paradigm, become largely ineffective.

\section{in conclusion}

There is no historical necessity for gridding to be state-related, but in the postsocialist war-time and post-war conditions of Dobrinja, the 'language of stateness' (Hansen \& Stepputat 2001: 5) was central to many evocations of it. I have proposed 'gridding' as an analytical tool that, complementing anthropology's great tradition of critically analysing catastrophic state encroachments and people's evasion, helps to also capture such hope for the state-the suppressed yearnings, loud clamourings and tireless struggles of people to be incorporated into griddings of improvement, and their investment in becoming, not to put too fine a point to it, part of legible populations. The fact that at other points and in other ways these same people also wish to remain illegible and ungridded does not discount this desire as irrelevant, nor does the fact that they seek incorporation on their own terms.

Whenever the questions addressed here impose themselves in other settings-and I would imagine they do so with increasing frequency-I invite anthropologists to refrain from rushing into the libertarian approach. Rather than preposition anthropology within hope against the great beast of the state, I suggest we be prepared to replicate our interlocutors' hopes for as well as against the state. Let us at least pause before flattening people's grid desire into proof of the internalisation of insidious, oppressive statecraft. Let us at least pause before dismissing any politically critical potential it may hold. In the face of neoliberal reconfigurations of discipline, sovereignty and government, we would do well to develop analytical tools to capture any politically critical potential, not just in grid evasion, but also in the very belly of the beast: people's hope for the state.

\section{Acknowledgements}

I thank the people in Dobrinja who shared their experiences with me. For research assistance I thank Melina Sadiković, and for constructive criticism Čarna Brković, Jon Mair, Larisa Kurtović, Madeleine Reeves, Nejra Nuna Čengić, Sarah Green, Soumhya Venkatesan, Vanja Čelebičić and seminar participants at the Universities of Berlin (Humboldt), Beograd, Chicago, Manchester, Tampere, Uppsala and Zagreb. I am grateful for financial support from the Leverhulme Trust and the British Academy.

\section{References cited}

Agamben, Giorgio. 1998. Homo Sacer: Sovereign Power and Bare Life. Stanford: Stanford UP. Aretxaga, Begoña. 2003. Maddening States. Annual Review of Anthropology 32:393-410. Bećirović, Hajriz. 2003. Dobrinjska Ratna Drama. Sarajevo: JOB BiH "Unija veterana". Berman, David M. 2007. The War Schools of Dobrinja. San Francisco: Caddo Gap Press. Camus, Albert. 1985 (1951). L'Homme Revolté. Paris: Gallimard. Clastres, Pierre. 1974. La Societé Contre L'État. Paris: Minuit. 
Corbridge, Stuart, Glyn Williams, Manoj Srivastava \& René Véron. 2005. Seeing the State: Governance and Governmentality in India. Cambridge: Cambridge UP.

Critique of Anthropology 2012, 32: 2. Special Issue: Anthropology and Anarchy.

Das, Veena \& Deborah Poole (eds.). 2004. Anthropology in the Margins of the State. Santa Fe: School of American Research Press.

Dobrinja Danas: Bilten Mjesne zajednice. 1995. No. 50, 27 March.

Dobrinja Ratne novine 1. Dobrinjske Brigade. 1992. Prva Dobrinjska brigada - primjer drugima. 19 September 1992: 3.

—. 1992. Dobrinja se odbranila srcem. 19 September 1992: 14.

-. 1992. Ni sila, ni oružja / Ponovo Dobrinja. 23 November 1992: 2.

Dunn, Elizabeth. 2008. Postsocialist Spores: Disease, Bodies and the State in the Republic of Georgia. American Ethnologist 35(2):243-258.

Fehérváry, Krisztina. 2002. American Kitchens, Luxury Bathrooms, and the Search for a 'Normal' Life in Postsocialist Hungary. Ethnos 67(3):369-400.

Ferguson, James \& Akhil Gupta. 2002. Spatialising States: Toward an Ethnography of Neoliberal Governmentality. American Ethnologist 29(4):981-1002.

Foucault, Michel. 1991. Governmentality. In The Foucault Effect: Studies in Governmentality, edited by Graham Burchell, Colin Gordon \& Peter Miller. 73-86. London: Harvester Wheatsheaf.

Galbraith, Marysia. 2003. 'We Just Want To Live Normally": Intersecting Discourses of Public, Private, Poland, and the West. Journal of the Society for the Anthropology of Europe 3(1): 2-13.

Graeber, David. 2007. Possibilities: Essays on Hierarchy, Rebellion and Desire. Oakland: AK Press.

Greenberg, Jessica. 2011. On The Road To Normal: Negotiating Agency and State Sovereignty in Postsocialist Serbia. American Anthropologist 113(1):88-100.

Hamzić, Muharem. 2004. Dobrinjska Tvrđava. Sarajevo: Općina Novi Grad.

Hansen, Thomas Blom \& Finn Stepputat. 2001. Introduction. In States of Imagination: Ethnographic Explorations of the Postcolonial State, edited by Thomas Blom Hansen and Finn Stepputat. 138. Durham: Duke UP.

International Crisis Group (ICG) 1998. Minority Return or Mass Relocation? Sarajevo: ICG.

Jansen, Stef. 2005. Antinacionalizam: Etnografija Otpora u Zagrebu i Beogradu (transl. A. Bajazetov). Beograd: XX Vek.

-. 2008. Troubled Locations: Return, the Life Course and Transformations of Home in BosniaHerzegovina. In Struggles for Home: Violence, Hope and the Movement of People, edited by Stef Jansen \& Staffan Löfving. 43-64. Oxford: Berghahn.

-. 2009. After the Red Passport: Towards an Anthropology of the Everyday Geopolitics of Entrapment in the EU's Immediate Outside. Journal of the Royal Anthropological Institute 15(4):815-832.

-. 2010. Of Wolves And Men: Postwar Reconciliation and the Gender of Inter-National Encounters. Focaal 57:33-49.

Latour, Bruno. 2005. Reassembling the Social. Oxford: Oxford UP.

Li, Tanya M. 2007. The Will to Improve: Governmentality, Development and the Practice of Politics. Durham: Duke UP.

Maček, Ivana. 2009. Sarajevo Under Siege: Anthropology in Wartime. University Park: Pennsylvania UP.

Miyazaki, Hirokazu. 2004. The Method of Hope: Anthropology, Philosophy and Fijian knowledge. Stanford: Stanford UP.

Musić, Aida (ed.) 1998. OŠ Skender Kulenović. Sarajevo: OŠ Skender Kulenović.

Navaro-Yashin, Yael. 2002. Faces of the State: Secularism and Public Life in Turkey. Princeton: Princeton UP.

Nuijten, Monique. 2003. Power, Community and the State: the Political Anthropology of Organisation in Mexico. London: Pluto.

Obeid, Michelle. 2010. Searching for the "Ideal Face of the State" in a Lebanese Border Town. Journal of the Royal Anthropological Institute 16(2):330-346. 
Ong, Aihwa \& Stephen J. Collier (eds.) 2005. Global Assemblages: Technology, Politics, and Ethics as Anthropological Problems. Oxford: Blackwell.

Oslobođenje. 1994. Dobrinja neće postati etnički čista. 30 December 1994:8.

-. 2001. Dobrinjska komuna: civilizacijska pouka iz nedavne bh. historije. 29 April 2001:6.

Rausing, Sigrid. 2002. Re-Constructing the Normal: Identity and the Consumption of Western Goods in Estonia. In Markets and Moralities: Ethnographies of Postsocialism, edited by Ruth Mandel \& Caroline Humphrey. 127-142. London: Berg.

Reeves, Madeleine. 2011. Fixing the Border: On the Affective Life of the State in Southern Kyrgyzstan. Environment and Planning D: Society and Space 29(5):905-923.

Scott, James C. 1998. Seeing Like A State: How Certain Schemes to Improve the Human Condition Have Failed. New Haven: Yale UP.

- 2009. The Art Of Not Being Governed: An Anarchist History of Upland Southeast Asia. Yale: Yale UP.

Spencer, Jonathan. 2007. Anthropology, Politics and the State: Democracy and Violence in South Asia. Cambridge: Cambridge UP.

Ssorin-Chaikov, Nikolai. 2003. The Social Life of the State in Subarctic Siberia. Stanford: Stanford UP.

Stefansson, Anders H. 2006. Homes in the Making: Property Restitution, Refugee Return, and Senses of Belonging in a Post-War Bosnian town. International Migration 44(3):115-139.

Šurković, Zekija (ed.). 2003. Gimnazija Dobrinja. Sarajevo: Gimnazija Dobrinja.

${ }^{1}$ Following European conventions, I use the term 'libertarian' to denote a concern with autonomy and freedom from grids. The fact that this concern may be found in anarchism, certain forms of socialism and right-wing individualism should not lead us to overlook important differences between them.

2 This may be related to a specific generational conjuncture in academia marked by disillusion with modernist grand narratives, and by an institutional framework in which most senior anthropologists in North America and Western Europe operate from positions where they can remain largely unaware of the role of statecraft in the creation of conditions of possibility for their work and lives. This question must remain beyond the scope of this article.

${ }^{3}$ Beyond that, much work focuses on affective investment in the nationalist wholeness projected by statecraft, but here I draw attention to more practical-processual dimensions of grid-making.

${ }^{4}$ Elsewhere I explore the tensions within yearnings for 'normal lives', taking into account the 'everyday geopolitics' (Jansen 2009) of the $\mathrm{BiH}$ semi-protectorate against the background of its Cold War positioning of non-aligned Yugoslav self-management socialism and of the 1992-1995 war. Space restrictions prevent me from developing this here.

${ }^{5}$ This article focuses on people who spent the war years in Dobrinja. Over 10,000 persons with Serbian national backgrounds stayed in besieged Sarajevo (ICG 1998: 3).

${ }^{6}$ Much of this war-time organisation was modelled on the Yugoslav socialist doctrine of Opštenarodna odbrana i društvena samozaštita (ONO i DSZ, All-People's Defence and Societal Self-Protection), inspired by the WWII Partisan guerrilla (Bećirović 2003; Hamzić 2004).

7 My description of war-time schooling is based on conversations with teachers, pupils and parents in Dobrinja (2008-10), on press reports, memoirs, and school documents. All translations are mine. For a detailed reconstruction of war-time schooling in Dobrinja, see Berman 2007.

${ }^{8} \mathrm{~A}$ legal-administrative requirement, at times the School Diary clearly also addresses a future audience, positioning itself as testimony and the Gimnazija as a self-conscious historical agent.

${ }_{9}^{9}$ In some ways the disintegration of pre-war grids was also experienced as beneficial, and some handsomely profited from the unprecedented opportunities it provided. Yet most emphasised the opposite side of the coin. 